\title{
Correction to: Differentiating neurons derived fromhuman umbilical cord blood stem cells work as a test system for developmental neurotoxicity
}

\author{
Mahendra P. Kashyap ${ }^{1}$ - Vivek Kumar ${ }^{1} \cdot$ Abhishek K. Singh ${ }^{1} \cdot$ Vinay K. Tripathi ${ }^{1} \cdot$ Sadaf Jahan $^{1} \cdot$ Ankita Pandey $^{1}$. \\ Ritesh K. Srivastava $^{1} \cdot$ Vinay K. Khanna ${ }^{1}$ - Aditya B. Pant ${ }^{1}$
}

Published online: 1 July 2019

(C) Springer Science+Business Media, LLC, part of Springer Nature 2019

\section{Correction to: Mol Neurobiol (2015) 51:791-807 https://doi.org/10.1007/s12035-014-8716-7}

The original version of this article unfortunately contained a mistake. The acknowledgment published was incomplete. The authors hereby publish the correct acknowledgment statement below.

\section{Acknowledgement \\ Authors are grateful to the Director, CSIR-IITR, Lucknow, India, for his keen interest in the study. The work was supported by the Council of Scientific \& Industrial Research (CSIR), New Delhi, India, [Grant No. BSC0111/ INDEPTH/CSIR Network Project] and the Department of Biotechnology (DBT), New Delhi, India [Grant No. 102/IFD/SAN/PR-1524/2010-2011]. The funders had no role in study design, data collection}

and analysis, decision to publish, or preparation of the article. Authors are grateful to the Oxford University Press as the images ' $a$ ' and ' $e$ ' in Figure No. 1 have also been presented earlier in our paper (images ' $a$ ' and ' $b$ ' of Figure 1) published in Toxicological Sciences. The details of the paper are as under reference [15]:

AK Singh, MP Kashyap, S Jahan, V Kumar, VK Tripathi, MA Siddiqui, S Yadav, VK Khanna, V Das, SK Jain, AB Pant (2012). Expression and inducibility of cytochrome P450s (CYP1A1, 2B6, 2E1, 3A4) in human cord blood CD 34 (+) stem cell-derived differentiating neuronal cells. Toxicological Sciences. 2012;129(2):392-410 doi:10.1093/toxsci/kfs213.

Publisher's Note Springer Nature remains neutral with regard to jurisdictional claims in published maps and institutional affiliations.

The online version of the original article can be found at https://doi.org/ $10.1007 / \mathrm{s} 12035-014-8716-7$

Aditya B. Pant

abpant@ rediffmail.com

1 In Vitro Toxicology Laboratory, CSIR-Indian Institute of Toxicology Research, Post Box 80, MG Marg, Lucknow 226001, India 